\title{
Mineralogy and morphology of sand: Key parameters in the durability for its use in artificial beach nourishment
}

\author{
M. López, F. Baeza-Brotons, I. López, A.J. Tenza-Abril, L. Aragonés* \\ Dept. of Civil Engineering, University of Alicante, Carretera San Vicent del Raspeig s/n, 03690 Alicante, Spain
}

\section{A R T I C L E I N F O}

Article history

Received 26 March 2018

Received in revised form 2 May 2018

Accepted 3 May 2018

Available online $\mathrm{xxx}$

Editor: D. Barcelo

Keywords:

Accelerated wear particle test

Beach nourishment

X-ray diffraction

Morphology

SEM

Aggregate

\section{A B S T R A C T}

Sand is the third most consumed material in the world, although it is a very scarce material. An exhaustive knowledge of sand and its behaviour against the waves is important for selecting the most suitable material to avoid shoreline erosion. To this end, a pattern of behaviour against accelerated wear test has been sought for 26 sand samples with different characteristics and origins (natural, dredged and quarried), with a focus on their mineralogy as well as a comparison of beach evolution carried out by other authors. Several techniques have been applied for characterization: granulometry, calcimetry, XRD and SEM. The results show that the different degrees of sand grain wear are not only due to their size and mineralogy, but also to the morphology of the particles.

(C) 2017

\section{Introduction}

Coastal environment has been a growing concern among coastal engineers and researchers for many years. They work together to find ways of solving key problems that are visibly affecting the fragile shoreline, such as (i) the interaction between coastal defence structures and the sea, (ii) beach nourishment duration and its effect on marine biocenosis, and (iii) the consequence of sediment retention in dams and watercourse re-channelling, among others. It is a fact that the construction of certain structures, such as ports and dams, has a direct impact on the sediment contribution to beaches (Aragonés et al., 2016; Newton et al., 2012). Moreover, the scarce sand available from the contribution of rivers and ravines is widely used in the construction industry to produce concrete (Chaplot and Poesen, 2012).

In the last decade, there has been a trend towards soft interventions in coastal defence techniques, providing the endangered beaches with sand so as to mitigate the shoreline retreat (Burningham, 2006; Trembanis and Pilkey, 1998). Nevertheless, these soft techniques trigger an additional impact on the coastal environment, such as the significant degradation of the Posidonia oceanica (Aragonés et al., 2015; Pagán et al., 2016).

Anfuso et al. (2003) identified three major factors affecting the stability of the nourished beaches. The first factor is the designed beach profile. The second, the size, density, and porosity of the sediment (Román-Sierra et al., 2014). The third, the wave characteristics

\footnotetext{
* Corresponding author.

Email address: laragones@ua.es (L. Aragonés)
}

(Oliveira et al., 2017). Grain density and not grain size was found to have a decisive role in the durability of beach refill (Eitner, 1996; Roberts et al., 1998). Paterson and Hagerthey (2001) observed that the stability of the sediment is greatly affected by the activity not only of microorganisms, - bacteria, microalgae and fungi - but also of macro-organisms, such as worms, molluscs, and crustaceans in general. Such organisms act either as binders - increasing erosion resistance - or as degraders - through bioturbation (Karl and Novitsky, 1988). Other authors approach the study of seabed stability in terms of bed displacements in which grains of different sizes are taken into account. For instance, Van Ledden et al. (2004) and Hir et al. (2008) suggested that the relative size of coarse and fine particles in a mixture contributes to stabilizing the fine fraction. In this line, Bartke et al. (2013) conducted some erosion experiments with sand and silt, proving that seabed stability increased with the presence of small amounts of silt, and erosion shear stresses tended to occur at high flow velocities. However, the addition of fine particles to a thicker seabed does not always ensure stabilization. When the fine-grain content exceeds a certain percentage, the fine particles form a network around the coarser grains, interrupting intergranular contact. Then, the seabed erosion may be said to be predominantly carried out by the fine-grain fraction; in other words, the fine-grain fraction facilitates seabed erosion by transporting coarser sediments (Houssais and Lajeunesse, 2012; Iseya and Ikeda, 1987; Jackson and Beschta, 1984; Venditti et al., 2010a; Venditti et al., 2010b; Wilcock et al., 2001). Seabed stability, however, can also be influenced by some other parameters, such as grain shape (Komar and Li, 1986), mineralogy (López et al., 2016) and the wear of sediment particles (López et al., 2016). 
The process of beach erosion and sand grain abrasion initiates when a particle gets dislocated by the force of the waves, which takes place when the fluid's upsurge force is greater than the counteracting resistance of the particle, which is a function of its weight, its angle, and the waves' lifting and dragging force (Allen, 1970; Komar, 1987; Van Rijn, 2007). The different processes by which particles are abraded are as follows: (i) particle wear by shock, (ii) particle break-

\section{Table 1}

Name of the beach and origin of the sand samples collected in this study. Origin of the sample: i) natural, beach nourished in a natural way; ii) quarry, beach artificially nourished by aggregate from a quarry; iii) dredging, beach artificially nourished by dredging nearby area.

\begin{tabular}{lll}
\hline Name of the beach & Sand origin & Municipality (province)/country \\
\hline 1 Acapulco & Natural & /Mexico \\
2 Aguamarina & Natural & Orihuela (Alicante)/Spain \\
3 Albir & Natural & Alfaz del Pi (Alicante)/Spain \\
4 Arenal & Dredging & Calpe (Alicante)/Spain \\
5 Arenales del Sol & Natural & Elche (Alicante)/Spain \\
6 Bol Nou & Natural & La Vila Joiosa (Alicante)/Spain \\
7 Caló des Moro & Natural & Santanyí (Mallorca)/Spain \\
8 Caribe & Natural & /Dominican Republic \\
9 Carrer la Mar & Dredging & El Campello (Alicante)/Spain \\
10 Deveses & Quarry & Dénia (Alicante)/Spain \\
11 El Conde & Natural & Pilar de la Horadada (Alicante)/Spain \\
12 El Cura & Natural & Torrevieja (Alicante)/Spain \\
13 Fustera & Quarry & Benissa (Alicante)/Spain \\
14 Guardamar & Natural & Guardamar del Segura (Alicante)/Spain \\
15 Krabi & Natural & /Thailand \\
16 La Caleta & Dredging & Cádiz (Cádiz)/Spain \\
17 Levante & Natural & Benidorm (Alicante)/Spain \\
18 Marineta Cassiana & Dredging & Dénia (Alicante)/Spain \\
19 Molinos y Palmeras & Quarry & Dénia (Alicante)/Spain \\
20 Portet de Moraira & Dredging & Teulada (Alicante)/Spain \\
21 Phi Phi & Natural & /Thailand \\
22 Playa Centro & Dredging & Benidorm (Alicante)/Spain \\
23 Playa Lisa & Dredging & Santa Pola (Alicante)/Spain \\
24 S'Amarador & Natural & Santanyí (Mallorca)/Spain \\
25 San Juan & Dredging & Alicante (Alicante)/Spain \\
26 Sottomarina & Natural & Chioggia (Venice)/Italy \\
\hline
\end{tabular}

down into its different mineral fractions, and/or (iii) particle dissolution -carbonate fraction (López et al., 2016). This last process may be aggravated by ocean acidification due to the increase in $\mathrm{CO}_{2}$ emissions (Steinfeldt et al., 2009).

The large number of factors that influence the retreat of the coastline complicate its precise modelling (Williams et al., 2017). It is known wave energy erodes beaches faster if the sand grains are smaller (same density). This paper examines a wide range of grain parameters that are not typically studied. The grain parameters that control the reduction of the grain size (abrasion and dissolution) are analysed. The aim of the study is to optimise the selection of sand (size, composition, texture) to avoid a rapid reduction in the size of the sand and the consequent erosion of the beach in feeding projects. For this purpose, the behaviour of different sediment samples in relation to wear is studied, and their relationship with the granulometry, mineralogy and morphology of the sand grains is analysed.

\section{Materials and methods}

\subsection{Materials}

Table 1 shows the names and origins of 26 sand samples, of which most (19) came from beaches located in the province of Alicante (Spain). We added 2 more beaches from Mallorca (Spain) and 5 more from other countries (Fig. 1) to extend our analysis and compare results. The sand beach samples feature different origins - from natural beaches, from dredging, and from quarry.

All the analysed samples were taken directly from the beach. For sampling, the top $10 \mathrm{~cm}$ layer of sand was removed, and then a sample of $500 \mathrm{~g}$ of sand was taken. Four samples were taken at evenly distributed points along the beach ( 3 from the shoreline - centre and ends - and 1 from the centre of the dry beach). The samples were homogenised and divided by quartering for each test in the laboratory. In addition, the granulometry of the 4 samples from the same beach was compared and it was found to be very similar.

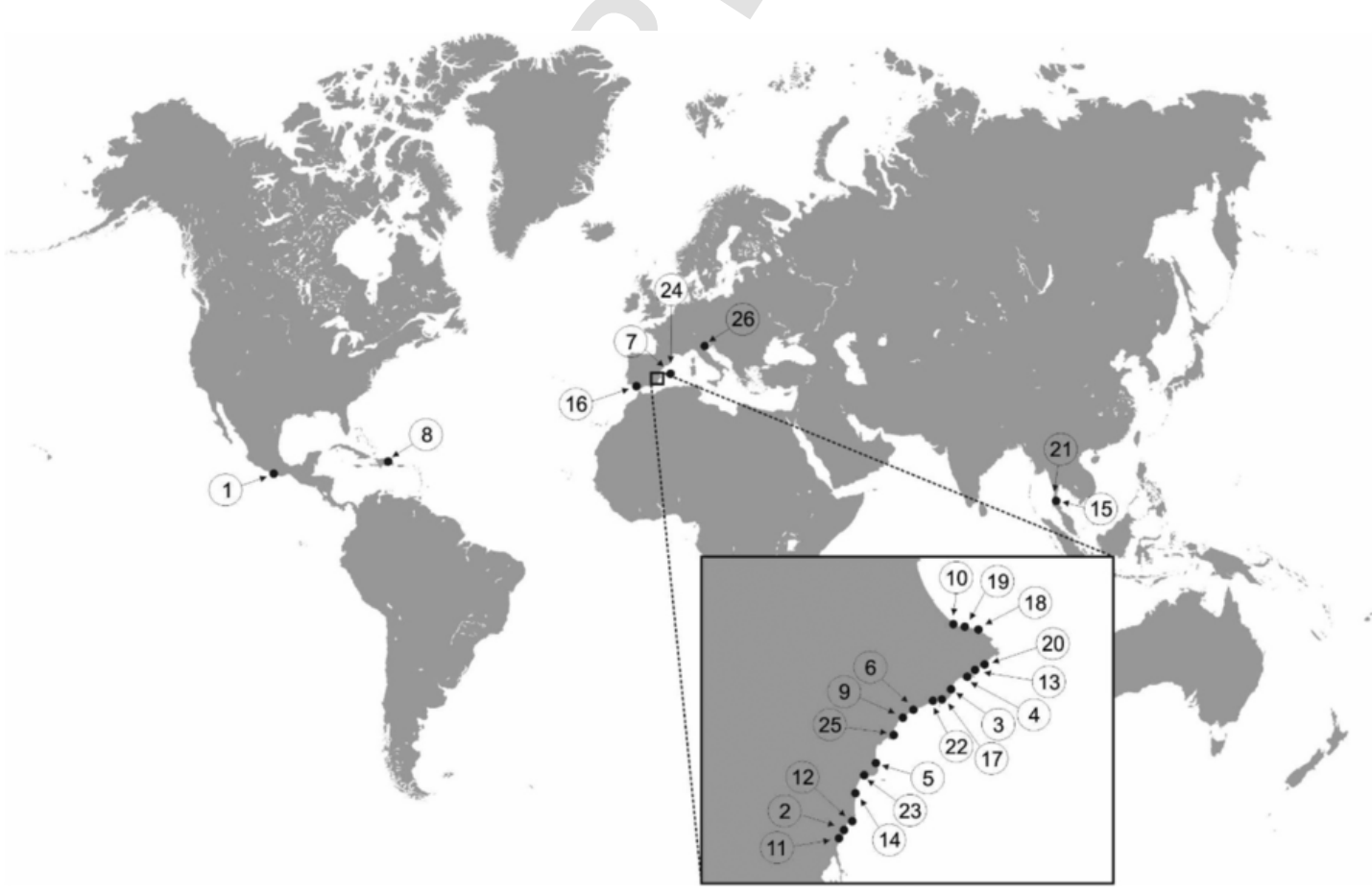

Fig. 1. Black dots indicate the sampling beach sites. 
When we refer to the origin of the sand (natural, dredged or quarry sand) we are referring to the origin of the sand prior to dumping it on the beach, since as indicated above all the analysed samples were taken on the beach.

\subsection{Experimental methodology}

We conducted five tests on the sand samples for their characterization: (i) particle size distribution, (ii) Calcimetry, (iii) accelerated particle wear (APW), (iv) X-ray diffraction (XRD), (v) scanning electron microscopy (SEM). In addition, we applied the SPSS 22.0 code (from SPSS Inc.) for a statistical analysis (vi) of large numbers of data.

(i) Particle size distribution of the sediment sample

We performed the particle size distribution tests following the UNE 103101 standards and complemented them with the UNE 7050-2 and the UNE 103100 codes. The particle size (in $\mathrm{mm}$ ) was obtained at the beginning of each APW test cycle. However, the median sediment size $\left(D_{50}\right)$ together with the specific surface area of each bulk sediment sample were acquired in two different ways: (i) from the whole sample, and (ii) after removing the finer particles (sizes $<0.063 \mathrm{~mm}$ ) from the sample before and after the APW tests were carried out.

(ii) Calcimeter analysis

We measured the percentage increase of $\mathrm{CaCO}_{3}$ content in the water resulting from the loss of carbonate in every sand sample undergoing the APW test applying the Bernard Calcimeter method (UNE 103200).

(iii) Accelerated particle wear (APW) test

We performed the APW test (López et al., 2016) to simulate the abrasion of the sand particle in the swash zone. For this purpose, we placed $75 \mathrm{~g}$ of the beach sand sample and $500 \mathrm{ml}$ of seawater (from the beach of Cabo de las Huertas in Alicante) in a magnetic stirrer at $1600 \mathrm{rpm}$ in 24-h cycles. We used the number of cycles applied to each sample needed to reduce the particle size to $<0.063 \mathrm{~mm}$ as a reference for determining the particle's wear resistance.

We decided the size $-0.063 \mathrm{~mm}$ - to be the necessary limit for the analysis results to be meaningful. In real situations, aggregates smaller than $0.063 \mathrm{~mm}$ tend to move deeper than the depth of closure (DoC) (Aragonés et al., 2017; López et al., 2016). That is, they tend to move towards the abyssal plains by gravitational forces, making them unavailable in the swash zone (Aragonés et al., 2016), and, therefore, unaccountable for our analysis. When the particles lose size, they move to a new position in the transversal of the coast, producing a new retreat of the shoreline (López et al., 2016).

(iv) X-ray diffraction (XRD)

We determined the mineralogical composition of the sand samples with a Brucker D8-Advanced diffractometer with a Göebel mirror by means of XRD. We first ground the samples in a ball mill at a size of $<0.063 \mathrm{~mm}$ and then performed an analysis at an acceleration voltage of $40 \mathrm{Kv}$ and a current of $40 \mathrm{~mA}$. The angular sweep (2-Theta) was $4^{\circ}$ to $60^{\circ}$ for all the samples. A Rietveld analysis with PANalytical Highscore Plus 4.6 software was carried out to quantify each phase present in the sample. For this purpose, we manually adjusted the background, cell parameters and peak parameter, and refined the scaling factor.

(v) Scanning electron microscopy (SEM)

We conducted a morphological analysis of the sediment by means of SEM. The equipment consisted of a Hitachi S3000N with a thermionic electron gun containing a Brucker X-ray detector XFlash 3001 for microanalysis (EDS) and mapping. The equipment allowed us to precisely know the microstructure and morphology of the particles as well as their likely face fracture and heterogeneity.

(vi) Statistical analysis

A summary of the most representative data obtained after the tests, including an overview of the characteristics of the samples studied, is provided due to the large number of samples, tests and data generated by the study. Detailed information about statistical analysis can be found in Table S1 (Supplementary material).

- Cycles (n): refers to the number of APW cycles needed to reduce the total grain sample to sizes $<0.063 \mathrm{~mm}$, indicating the end of its useful life and thus of the test.

- Particle size distribution: refers to the data obtained from particle size distribution tests.

- D0 and Dn: refer to median sediment size $\mathrm{D}_{50}$ before undergoing the APW test, in the first cycle (0), and in the last cycle (n), once the APW test has been carried out. In both cases, the results include all the particles that comprise the sample.

- D01, Du and D0n: refer to the diameter loss in percentage (\%) between cycle 0 and cycle $1(01)$, in the last cycle $(\mathrm{u})$, and between cycle 0 and cycle $n(0 n)$ of the APW test.

- M0 and Mn: refer to weight in grams before cycle 0 and after cycle $\mathrm{n}$ of the APW test. In neither case, were the particles $0.063 \mathrm{~mm}$ computed.

- M01, Mu and M0n: refer to weight loss in percentage between cycle 0 and cycle $1(01)$, in the last cycle (u), and between cycle 0 and cycle $n(0 \mathrm{n})$ of the APW test.

- S0 and Sn: refer to the average of the specific surface area (SSA) in $\mathrm{mm}^{2}$ before cycle 0 and after cycle $\mathrm{n}$ of the APW test. In both cases, the results include all the particles that comprise the sample.

- S0n: refers to the increase of SSA in percentage between cycle 0 and cycle $n(0 n)$.

$-\mathrm{CaCO}_{3}$ : refers to the amount of calcium carbonate dissolved in water accumulated in the $\mathrm{n}$ cycles of the APW test.

- Mineralogy: refers to the mineralogical composition of the sand sample in percentage (Rietveld analysis).

Based on the above data, a multivariate statistical analysis is performed, and the results are summarised as follows:

i) Statistical summary of all the variables under study. It includes such measurements as central tendency, variability and distribution arrangement. Particularly relevant are those features that determine whether the sample agrees with the normal Gauss Bell distribution, as is the case of the standardized Bias and Kurtosis. The values outside the range, i.e., between -2 and +2 , indicate significant deviation from the norm. The analysis was complemented with Box and Whiskers charts for variables showing statistics outside the normal range detected. Values distant from the norm were identified applying the Tukey test either as being three times greater than the interquartile range, or external - 1.5 times greater than the interquartile range. Outliers, samples with extreme values, were identified by the Grubb test. For Grubb, any value of $p<0.05$ means that this value is a significant aberrance. Students' statistics were also analysed, which measures the number of sample standard deviations from the average. All the information is listed in the supplementary material (Table S1).

ii) Study of correlations (matrix of correlations) between all the variables under study. It includes the following information: (i) the Pearson product moment correlations (r) between each variable pair. The $\mathrm{p}$-value derived from the analysis of variance (ANOVA). $\mathrm{P}$-values $<0.05$ were considered to be a significant result in this study; (ii) the determination coefficient $\mathrm{R}^{2}$ between 
variables and the degree of correlation according to the scale of Evans (Evans, 1996).

\section{Results and discussion}

\subsection{Median sediment size $\left(D_{50}\right)$ and specific surface area}

The study of beach nourishment requires the understanding of parameters such as the median particle size $\left(D_{50}\right)$, the sediment fall velocity, and the energy represented by the wave height and the period. These parameters allow coastal engineers to find out the equilibrium beach profile (EBP) and its lower DoC limit (Aragonés et al., 2016; Dean, 1973; Hallermeier, 1980; Hallermeier, 1978). In general, if the size of the nourishing sediment is larger than the original sediment on the beach, beach nourishment will be successful and therefore, stable (James, 1974). However, Table 2 shows that some of the sand samples with initial $\mathrm{D}_{50}$ (D0) larger than others undergo a lower number of cycles in the APW test. In reality, the rapid wear of the particles could lead to an unsuccessful beach nourishment even if the median size of the borrowed sediment was larger than the one on the beach.

Considering the results obtained, despite the following samples having a similar median particle size, samples from both (7) Caló des Moro $(0.286 \mathrm{~mm}-3$ cycles $)$ and from (19) Molinos y Palmeras $(0.322 \mathrm{~mm}-4$ cycles $)$ withstand lower number of cycles than samples from (22) Playa Centro $(0.268 \mathrm{~mm}-13$ cycles $)$ and (4) Arenal $(0.237 \mathrm{~mm}-7$ cycles $)$. Also, the very strong linear correlation between D0 and number of cycles $\left(r=0.94, \mathrm{R}^{2}=0.89\right)$ observed in Table 3 , appears to be highly influenced by the samples (3) Albir, (6) Bol Nou, (13) Fustera, and (22) Playa Centro. Since these samples were identified as outliers, we performed a linear and non-linear regression test again, but this time by omitting these outliers (Fig. 2) we observed that the linear correlation decreases to very weak (Fig. $3 ; \mathrm{R}^{2}=0.18$ ), while non-linear correlation is moderate (Fig. $3 ; \mathrm{R}^{2}=0.47$ ).

Table 3 also shows that the variables D0 and Dn (grain diameter after undergoing the last cycle of the APW test) have a very strong linear correlation $\left(\mathrm{r}=0.86, \mathrm{R}^{2}=0.74\right)$, highly influenced by the outliers. When these outliers were ignored, the correlation decreased substantially for both linear and non-linear correlation $\left(r=0.31, \mathrm{R}^{2}=0.09\right)$.

The variable $\mathrm{D} 0$, and consequently $\mathrm{S} 0$, was better rendered by the SSA increase along the aggregate life cycles (S0n). The greater initial median grain diameter, the greater the SSA increase after the last cycle of the APW test. If the best fit model is applied to both variables, D0 and S0n, regardless of the samples included in the analysis, they show a similar correlation between the two: (i) including outliers (3, 6,13 ), $r=0.85, R^{2}=0.73$ ); (ii) excluding outliers (Fig. 4), $\mathrm{R}^{2}=0.54$ for linear correlation and $\mathrm{R}^{2}=0.69$ for non-linear correlation.

We can conclude, therefore, by stating that $\mathrm{D}_{50}$ and the initial sand SSA (i.e., before undergoing the first APW test cycle), equivalent to D0 and S0, are factors that could influence beach nourishment durability (Chiva et al., 2018; Pagán et al., 2018) but are not decisive.

\subsection{Carbonate content}

Marine sediments contain a high proportion of carbonates. In fact, they form the second most abundant compounds in the oceans (Milliman and Syvitski, 1992). Quartz and bioclastic carbonate are the main sediment components (De Falco et al., 2003). Indeed, Table 1 illustrates that the main minerals present in our samples once analysed by XRD and quantified by Rietveld are precisely quartz and carbonate minerals. Thus, it is possible to indirectly evaluate the wear of the tested sand samples in terms of carbonate loss by measuring the $\mathrm{CaCO}_{3}$ content remaining in the water after each cycle applying the Bernard Calcimeter method.

An analysis of Table 3 (matrix of linear correlations) provides the following insights:

- Contrary to expectations, few and weak correlations between $\mathrm{CaCO}_{3}$ accumulated during the " $n$ " cycles and other variables can be appreciated. Table 3 shows the percentage of $\mathrm{CaCO}_{3}$ accumulated in the water for every sand sample in each cycle of the APW test. In general, the $\mathrm{CaCO}_{3}$ content does not increase steadily, which is attributed to the water used in the APW test. The same water was used throughout the test and consequently, part of the $\mathrm{CaCO}_{3}$ water content may have become suspended while the other part settled. When the sand samples went into the calcimetry test, the test was definitely unable to account for all the carbonate released. Samples 7, 10, 14, and 24 are exceptions because they withstood less number of cycles. López et al. (2016) state that the variation in $\mathrm{CaCO}_{3}$ percentage in the aqueous phase suggests that not only does a carbonate dissolution take place but also a colloidal dispersion is produced. The remaining variables behaved as expected - number of cycles, or any of the other variables that measure the variations of particle properties from the beginning to the end of their useful life- .

- The highest linear correlation detected between $\mathrm{CaCO}_{3}$ and the other variables was in the Aragonite content $\left(r=0.73, \mathrm{R}^{2}=0.54\right)$. Aragonite increase produces an increase in the dissolved carbonate. Applying a non-linear model, the strength of the relationship also increases, from moderate to strong $\left(\mathrm{r}=0.81, \mathrm{R}^{2}=0.66\right)$.

- The low amount of $\mathrm{CaCO}_{3}$ in the sand samples and the presence of quartz showed a weak relationship. The best linear adjustment model offered the following values: $\mathrm{r}=-0.55, \mathrm{R}^{2}=0.30$.

- An increase in dissolved carbonates takes place when a loss of the median diameter occurs in the first cycle (D01).

- To conclude, no clear pattern of behaviour can be observed as far as the $\mathrm{CaCO}_{3}$ water content is concerned. Although the presence of aragonite and quartz is influential, our results indicate that they are not decisive.

\subsection{Rapid size losses below $0.063 \mathrm{~mm}$ at the start or end of the useful life}

Sometimes, after beach nourishment takes place, a strong retreat of the shoreline is apparent in the first few years. Two of the factors that intervene in this process have been identified as (i) the formation of the natural profile after nourishment (Roeland and Piet, 1995), and (ii) a natural sand bar formation process after a storm (Grunnet and Ruessink, 2005). A third factor may also be involved, that is, the rapid wear of the sediment. Table 2 shows that some sand samples present grains of size $<0.063 \mathrm{~mm}$ after the first cycle of the APW test, which suggests those particles move to depths greater than the DoC (Aragonés et al., 2017; López et al., 2016) and therefore, responsible for such shoreline retreat. Evidence in beach sand samples such as (i) Playa Lisa (23) featuring a mass loss (M01) and median diameter loss in the first cycle (D01) of 62.5\% and 50.8\%, respectively; (ii) Caló des Moro (7), M01 $=40.8 \%$ and D01 $=61 \%$; (iii) Arenal, M01 $=20.6 \%$ and $\mathrm{D} 01=19.7 \%$; and Guardamar (14), M01 $=8.1 \%$ and D01 $=41.6 \%$.

Table 3 shows a generalized tendency between D01 and M01 in the linear correlation matrix. Both the median diameter loss of all the particles and the mass loss of the particles $>0.063 \mathrm{~mm}$ increase in a linear correlation coefficient of $r=0.78, R^{2}=0.61$. When samples outside the normal range are detected (Fig. 2; see Table S1 in the supplementary material), they are eliminated $(7,14,23)$, the correlation de- 
Table 2

Summary of the main characteristics of the sand samples.

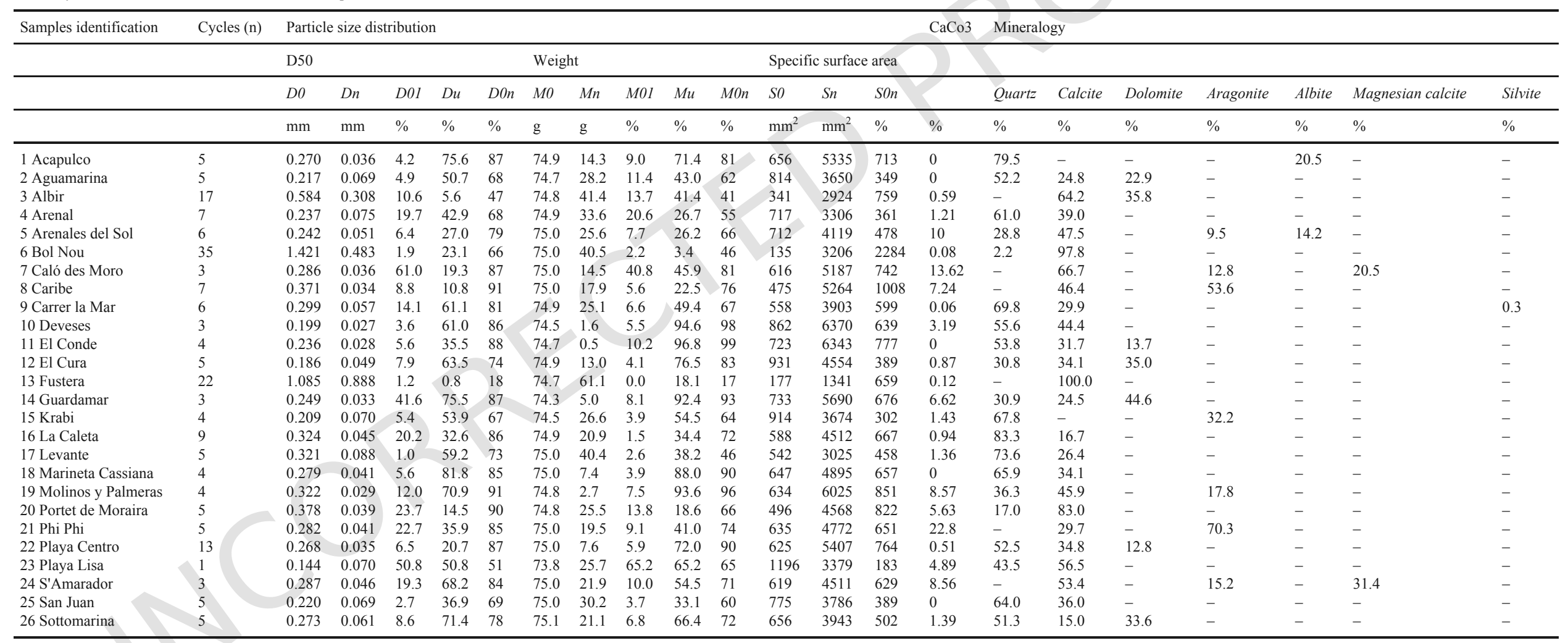


Table 3

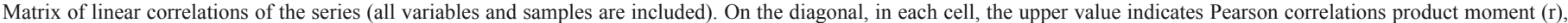
and the lower P-value of the Anova analysis; under the diagonal, the cell indicates the $\mathrm{R}^{2}$ coefficient coloured according to Evans scale.

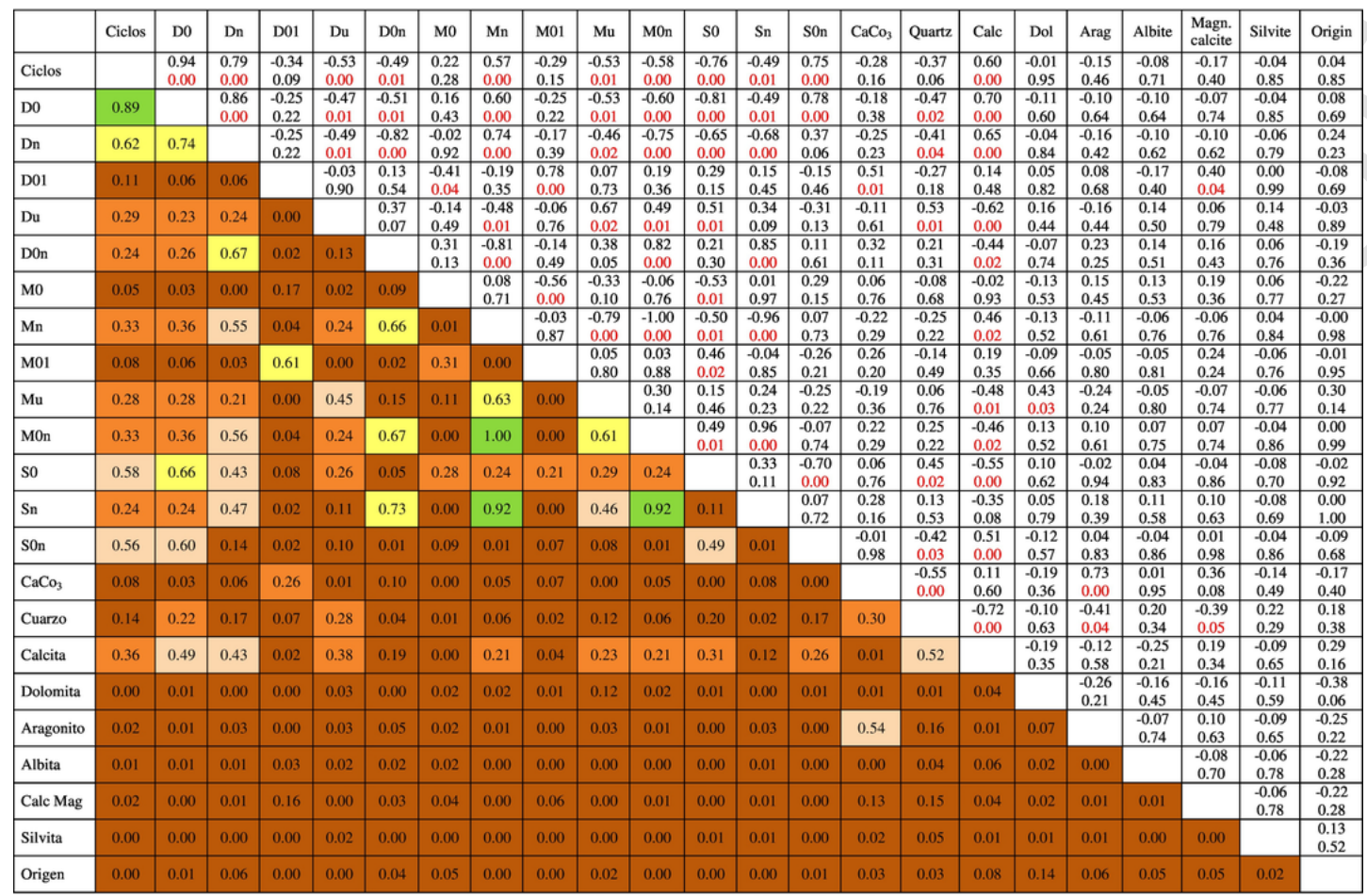

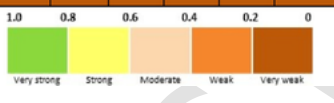

creases to $\mathrm{r}=0.62, \mathrm{R}^{2}=0.39$. However, this loss is not proportional to the initial sand sample size as seen in Table 3. A weak correlation coefficient is seen between D0 and M01 $(r=-0.25)$, and between D0 and $\mathrm{D} 01(\mathrm{r}=-0.25)$. It follows that beaches exist whose sediment contains a significant proportion of particles $<0.063 \mathrm{~mm}$ whose D0 value is low, and whose D01 value is lower than other samples with larger initial median diameter as is the case of Aguamarina (2) $4.2 \%$, Acapulco (1) 4.9\%, and Playa San Juan (25) 2.7\%, shown in Table 2.

At the end of the useful life of some sand sample particles it was notable that their size quickly decreases to $<0.063 \mathrm{~mm}$ in the last cycle of the APW test. Table 3 shows no significant correlation between the variables in general and those related to the last cycle. However, a weak correlation $(\mathrm{r}=0.29)$ between mass loss $(\mathrm{Mu})$ of particles $>0.063 \mathrm{~mm}$ and median diameter loss (Du) may be observed. The following sand sample behaviour can be highlighted:

- High Mu values: Deveses (10) with 94.6\%, and El Conde (11) with $96.8 \%$ feature loss of particles $>0.063 \mathrm{~mm}$ taking place in the last cycle of the APW test.

- High Du values: Acapulco (1) and Guardamar (14) whose median diameter loss in the last cycle with respect to the previous cycle is $>75 \%$. Sottomarina (26) presents a slightly less $(71.4 \%)$ median diameter loss.

- Some beaches show a good performance in the last cycle of the APW test. That is, particle wear has occurred in all sizes progressively throughout its useful life. They are Bol Nou (6) (Mu 3.4\%/ Du 23.1\%), Portet de Moraira (20) (Mu 18.6\%/Du 14.5\%), and Arenales del Sol (5) (Mu 26.2\%/Du 27.0\%). In Arenales del Sol, particle abrasion was correlated with the median sediment size, weight and surface up to the last cycle. However, in this last cycle the change was due to the carbonate dissolution $\left(10 \%\right.$ of $\mathrm{CaCO}_{3}$ in the last cycle) from the calcite and the aragonite present in the sand sample.

\subsection{Mineralogy and morphology}

As discussed above, $\mathrm{D}_{50}$ and $\mathrm{CaCO}_{3}$ are not the only factors intervening in sand against erosion. Furthermore, Table 3 shows no significant correlation between the variable "sand origin" and the rest of the variables. The sand origin, whether it is natural, dredged or quarry, appears to have no influence on and to be independent of the variables analysed, although in Pagán et al. (2018) demonstrated that the sediment coming from the same source -dredge- but different strata, behaved differently.

Table 2 shows samples offering low resistance to weathering, which were influenced by the dissolution of the carbonates present in their composition. The process showed the following characteristics: high percentages of dissolved $\mathrm{CaCO}_{3}$ at the end of its useful life, high $\mathrm{D}_{50}$ losses, close to $90 \%$, throughout the cycles (D0n), and low $\mathrm{D}_{50}$ losses in the last cycle (Du). The following sand samples cannot be described in terms of behaviour by analysing their mineralogical composition:

a. Phi Phi (21) with a $\mathrm{CaCO}_{3}$ content of $22.8 \%$ (considered distant from the mean; Fig. 2; see Supplementary material), D0n 85\%, Du $35.9 \%$, and Aragonite $70.3 \%$ );

b. Caló des Moro (7) with a $\mathrm{CaCO}_{3}$ content of $13.62 \%$, D0n $87 \%$, and Calcite $66.7 \%$;

c. Caribe (8) with a $\mathrm{CaCO}_{3}$ content of $7.24 \%$, D0n 91\%, Du $10.8 \%$, Aragonite $50 \%$ and Calcite $50 \%$;

d. Portet de Moraira (20) with a $\mathrm{CaCO}_{3}$ content of $5.63 \%$, D0n $90 \%$, Du $14.5 \%$, and Calcite $83 \%$. 

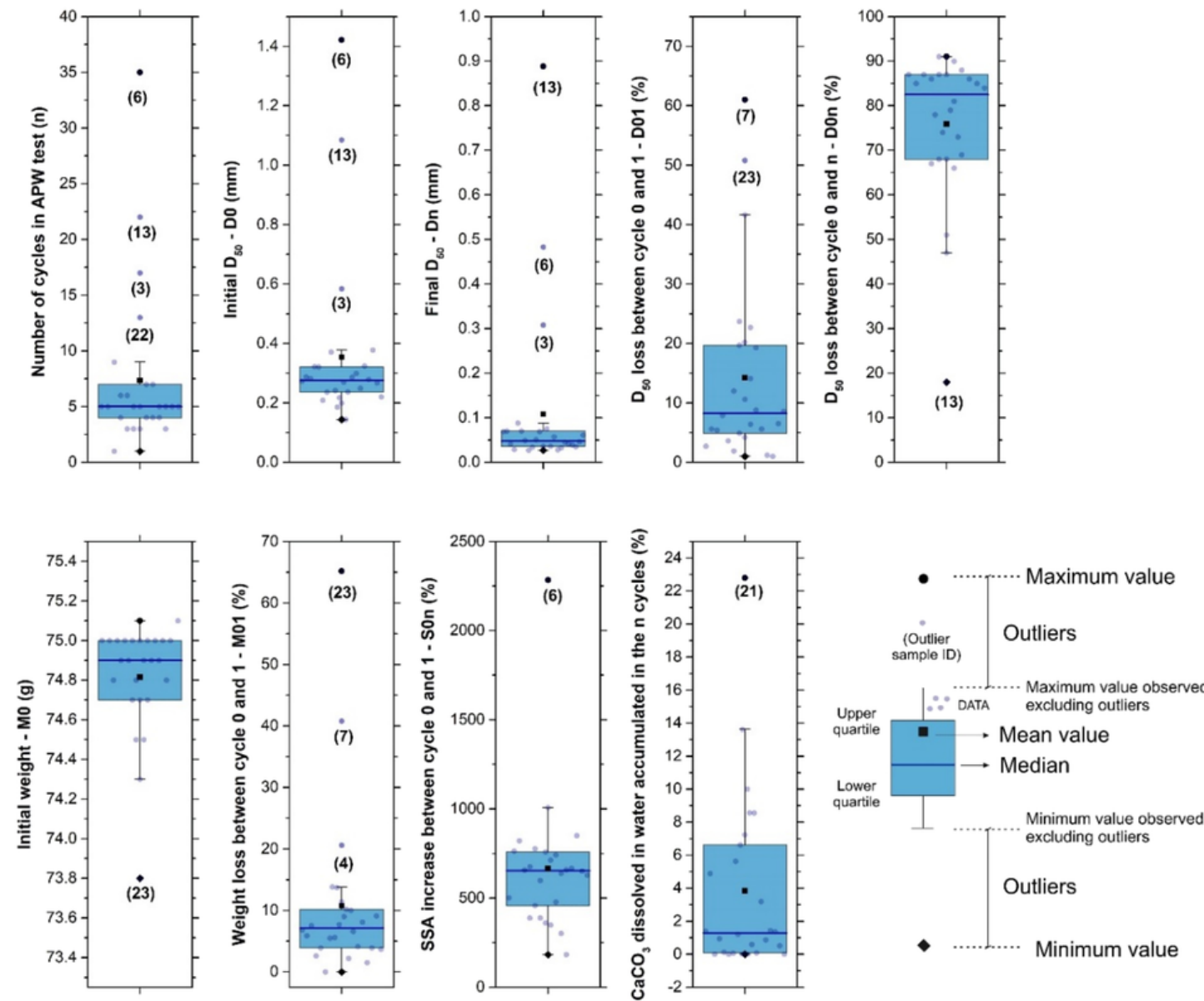

Fig. 2. Box and Whiskers plots of the variables with statistics outside the normal range.

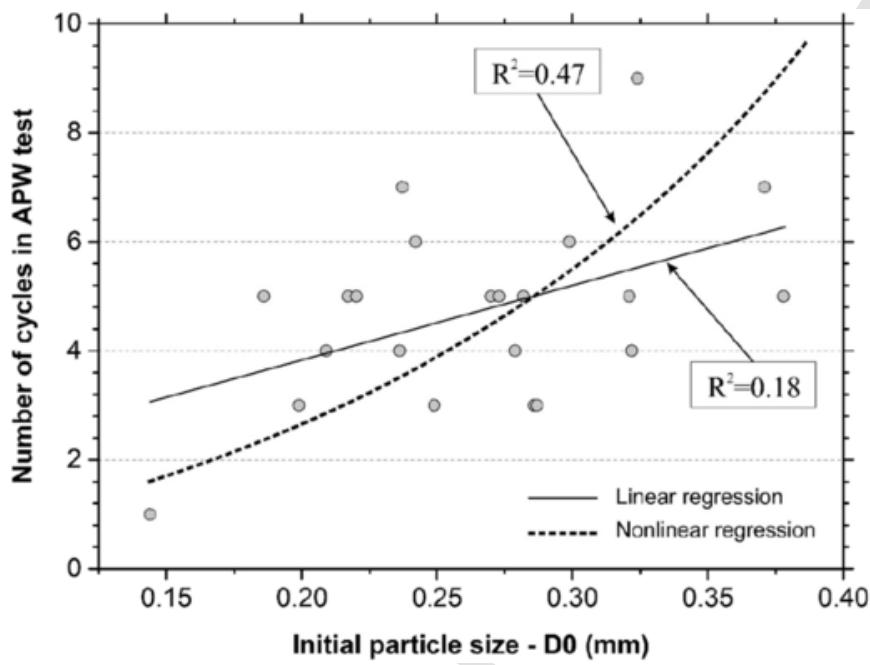

Fig. 3. Relationship between D0 ( $\mathrm{D}_{50}$ before the first cycle in the APW test) and Cycles (number of cycles in the APW test), not including the atypical samples 3, 6, 13 and 22.

Apart from the previous cases, the different behaviour of the following two sand samples, Playa Centro (22) and Marineta Cassiana (18), cannot be explained solely by analysing Table 2. Playa Centro (22) presented an initial $\mathrm{D}_{50}=0.268 \mathrm{~mm}$, a negligible carbonate water

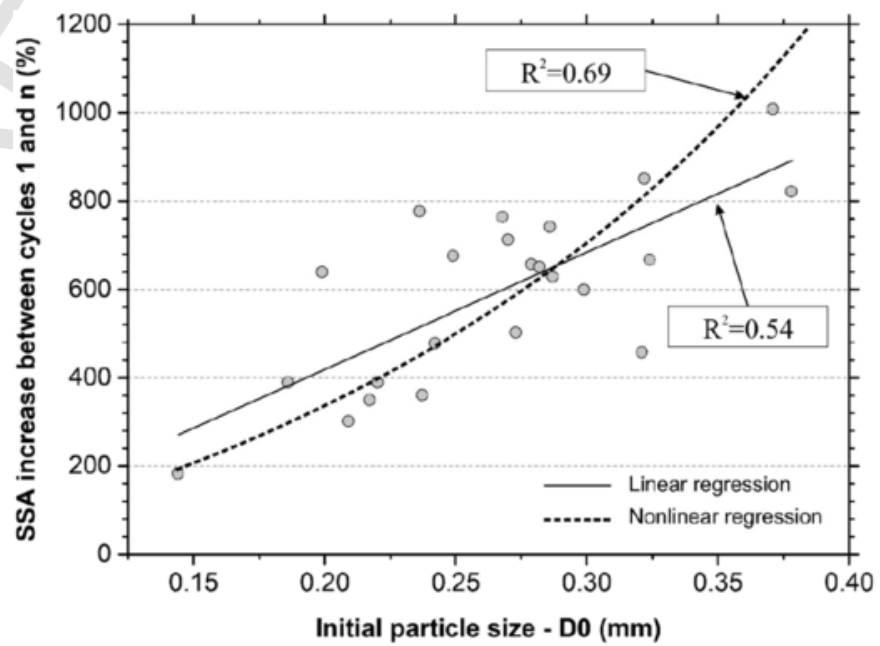

Fig. 4. Regression graph of the variables $\mathrm{D} 0\left(\mathrm{D}_{50}\right.$ before the first cycle in the APW test) and SOn (increase of the SSA between cycles 0 and $n$ ), not including atypical samples 3,6 and 13 .

content $=0.51 \%$, and wear resistance $=13$ cycles. Marineta Cassiana (18) presented a similar initial $\mathrm{D}_{50}=0.279 \mathrm{~mm}$, a carbonate water content $=0.0 \%$ and wear resistance $=4$ cycles - mineralogy obtained by XRD gave us for Playa Centro (22): 52.5\% Quartz, 12.8\% Dolomite, and 34.8 Calcite while for Marineta Cassiana (18): $65.9 \%$ 
Quartz, 34.1 Calcite. These differences in mineralogical content can be attributed to the weak Ca-Si clusters, weak transition zones in the minerals, and the weak angular grains with laminar structures seen in Marineta Cassiana (Fig. 5a). We understand that this morphology could accelerate the wear process. The grain samples in Playa Centro, on the other hand, were more homogeneous and rounded (Fig. 5b).

The existence of a weak correlation between variables Calcite and number of cycles Table 3. In a linear model, the greater the presence of the mineral, the longer the useful life of the aggregates $\left(\mathrm{p}, 0.60 / \mathrm{R}^{2}\right.$, 0.36 ). However, this result may have been greatly influenced by outliers (Fig. 2 and supplementary material) - samples distant from the norm- as is the case of Albir (3), Bol Nou (6), Fustera (13), and Playa Centro (22). When these samples were eliminated from the analysis, the linear correlation or non-linear regression model decreases to a very weak correlation (linear $\mathrm{p}=-0.14 / \mathrm{R}^{2}=0.02$; non-linear $\mathrm{p}=-0.30$ / $\mathrm{R}^{2}=0.09$ ) but the sign changes, indicating that as Calcite increases, the number of APW cycles decreases (Fig. 6).

Another remarkable linear correlation exists between Calcite and D0 (p, 0.70) and Calcite and Dn (p, 0.65). Should the outliers (3), (6), and (13) be eliminated in either of the aforementioned two cases, these correlations practically disappear. Their longer lifetime may well reside the fact that the particles are homogeneous and lack fissures (Fig. 5c, Fustera (13)).

In general, the presence of Quartz in the samples appears to have a lower influence than that of Calcite on the same variables. The only variable in which the Quartz content is more meaningful than the Calcite content is in $\mathrm{D}_{50}$ variation in the last cycle $(\mathrm{Du})$. Typically, when Quartz particles are laminated, the sand grains present fractures and fissures, which cause the rapid wear of the sample, as can be seen in Fig. 5d for Guardamar (14).

\section{Conclusions}

Coastal erosion is influenced by many factors but sediment is one of the most important factors. Thus, after analysing grains of sand from different beaches around the world, the following conclusions can be made:

- $\mathrm{D}_{50}$ is relevant, but not a decisive factor to explain the evolution of the shoreline.

- High Calcite sand content is related to the rapid wear of the samples whereas a higher Quartz content results in higher wear resistance.

- The morphology of the particle can have either a positive (very slow abrasion rates) or a negative (very rapid abrasion rate) influence on the sample wear.

Therefore, effective and sustainable beach nourishment requires not only analysing grain size and mineralogy but also morphology factors need be taken into account. The first step is to achieve a sediment with the least possible wear and tear by using homogeneous rounded particles with neither fissures and nor conglomerates of different minerals.

However, although the behaviour of different sand samples in relation to the APW test has been studied, the relationship between this laboratory test and a widescale application represents a future next step. In addition, other types of sediment with other minerals could be studied to establish if behaviour is better, worse or similar to those already studied.

Supplementary data to this article can be found online at https:// doi.org/10.1016/j.scitotenv.2018.05.024.

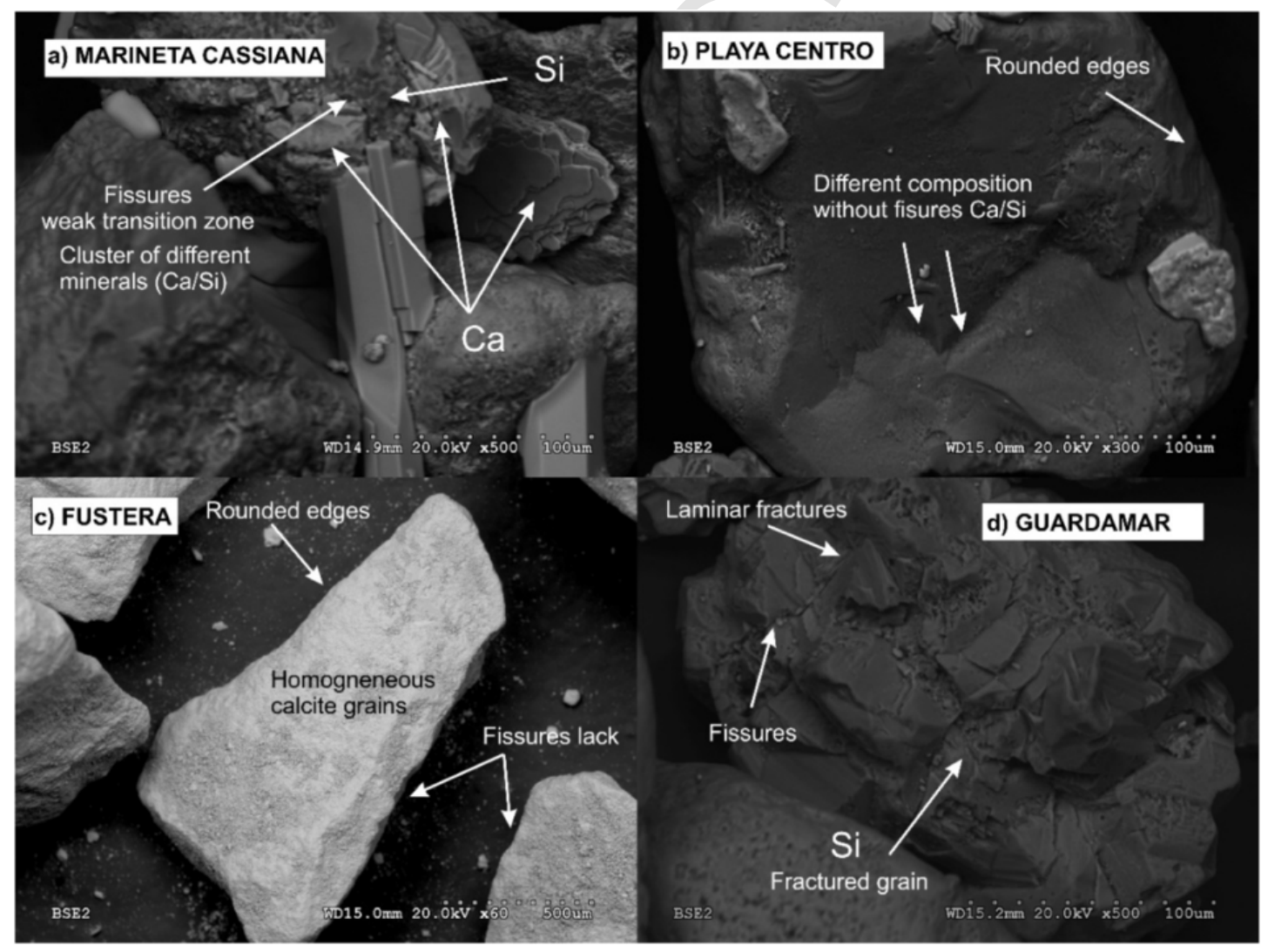

Fig. 5. SEM images of some sand samples. 


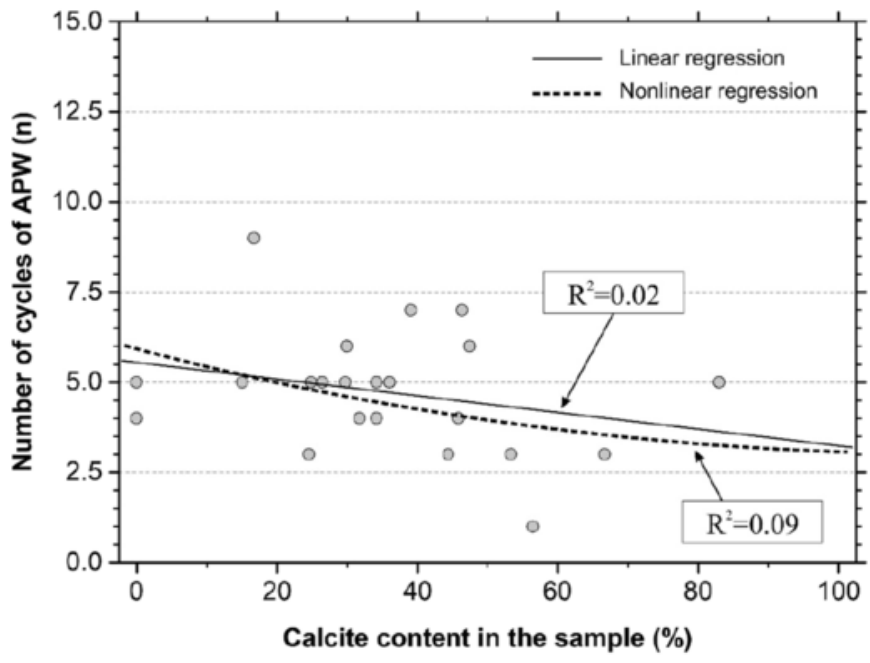

Fig. 6. Relationship between calcite content and number of total cycles.

\section{Uncited references}

Une 103 100: 1995, 1995

Une 103 101: 1995, 1995

Une 103 200: 1993, 1993

Une 7050-2: 1997, 1997

\section{Acknowledgements}

This work was partially supported by the Universidad de Alicante through the project "Estudio sobre el desgaste y composición de los sedimentos y su influencia en la erosión de las playas españolas" (GRE16-09).

\section{References}

Allen, J.R., 1970. Physical Processes of Sedimentation. American Elsevier Pub. Co. Anfuso, G., Martínez Del Pozo, J.A., Gracia, F.J., López-Aguayo, F., Cassar, M., Van Der Maarel, E., 2003. Long-shore distribution of morphodynamic beach states along an apparently homogeneous coast in SW Spain. J. Coast. Conserv. 9 (1), 49-56.

Aragonés, L., García-Barba, J., García-Bleda, E., López, I., Serra, J.C., 2015. Beach nourishment impact on Posidonia oceanica: case study of Poniente Beach (Benidorm, Spain). Ocean Eng. 107, 1-12.

Aragonés, L., Pagán, J.I., López, M.P., García-Barba, J., 2016. The impacts of Segura River (Spain) channelization on the coastal seabed. Sci. Total Environ. 543, Part A, 493-504.

Aragonés, L., Pagán, J.I., López, I., Serra, J.C., 2017. Depth of closure: new calculation method based on sediment data. Int. J. Sediment Res.(In press).

Aragonés, L., Serra, J.C., Villacampa, Y., Saval, J.M., Tinoco, H., 2016. New methodology for describing the equilibrium beach profile applied to the Valencia's beaches. Geomorphology 259, 1-11.

Bartke, G., Bryan, K.R., Pilditch, C.A., Huhn, K., 2013. On the stabilizing influence of silt on sand beds stabilizing influence of silt on sand beds. J. Sediment. Res. 83 (8), 691-703.

Burningham, H., 2006. Introduction to coastal processes \& geomorphology. J. Coast. Res. 22 (6), 1589-1590.

Chaplot, V., Poesen, J., 2012. Sediment, soil organic carbon and runoff delivery at various spatial scales. Catena 88 (1), 46-56.

Chiva, L., Pagán, J.I., López, I., Tenza-Abril, A.J., Aragonés, L., Sánchez, I., 2018. The effects of sediment used in beach nourishment: study case El Portet de Moraira beach. Sci. Total Environ. 628-629, 64-73.

De Falco, G., Molinaroli, E., Baroli, M., Bellacicco, S., 2003. Grain size and compositional trends of sediments from Posidonia oceanica meadows to beach shore, Sardinia, western Mediterranean. Estuar. Coast. Shelf Sci. 58 (2), 299-309.

Dean, R.G., 1973. Heuristic Models of Sand Transport in the Surf Zone. In: Proceedings of the First Australian Conference on Coastal Engineering (Sydney, Australia). pp. 215-221.
Eitner, V., 1996. The effect of sedimentary texture on beach fill longevity. J. Coast Res. 12 (2), 447-461.

Evans, J.D., 1996. Straightforward Statistics for the Behavioral Sciences. Brooks/Cole.

Grunnet, N.M., Ruessink, B.G., 2005. Morphodynamic response of nearshore bars to a shoreface nourishment. Coast. Eng. 52 (2), 119-137.

Hallermeier, R.J., 1978. Uses for a calculated limit depth to beach erosion. In: Proceedings of the 16th International Conference on Coastal Engineering (Hamburg, Germany). pp. 1493-1512.

Hallermeier, R.J., 1980. A profile zonation for seasonal sand beaches from wave climate. Coast. Eng. 4, 253-277.

Hir, P.L., Cann, P., Waeles, B., Jestin, H., Bassoullet, P., 2008. Chapter 11 Erodibility of natural sediments: experiments on sand/mud mixtures from laboratory and field erosion tests. In: Kusuda, T., Yamanishi, H., Spearman, J., Gailani, J.Z. (Eds.), Proceedings in Marine Science. Elsevier, pp. 137-153.

Houssais, M., Lajeunesse, E., 2012. Bedload transport of a bimodal sediment bed. J. Geophys. Res. Earth Surf. 117 (F4), (F04015).

Iseya, F., Ikeda, H., 1987. Pulsations in bedload transport rates induced by a longitudinal sediment sorting: a flume study using sand and gravel mixtures. Geogr. Ann. Ser. A Phys. Geogr. 69 (1), 15-27.

Jackson, W.L., Beschta, R.L., 1984. Influences of increased sand delivery on the morphology of sand and gravel channels. J. Am. Water Resour. Assoc. 20 (4), 527-533.

James, W.R., 1974. Beach fill stability and borrow material texture. In: Proceedings of the 14th International Conference on Coastal Engineering (Copenhagen, Denmark). pp. 1334-1349.

Karl, D.M., Novitsky, J.A., 1988. Dynamics of microbial growth in surface layers of a coastal marine sediment ecosystem. Mar. Ecol. Prog. Ser. 50 (1/2), 169-176.

Komar, P.D., 1987. Selective grain entrainment by a current from a bed of mixed sizes: a reanalysis. J. Sediment. Res. 57 (2), 203-211.

Komar, P.D., Li, Z., 1986. Pivoting analyses of the selective entrainment of sediments by shape and size with application to gravel threshold. Sedimentology 33 (3), 425-436.

López, I., López, M., Aragonés, L., García-Barba, J., López, M.P., Sánchez, I., 2016. The erosion of the beaches on the coast of Alicante: study of the mechanisms of weathering by accelerated laboratory tests. Sci. Total Environ. 566-567, 191-204.

López, M., López, I., Aragonés, L., Serra, J.C., Esteban, V., 2016. The erosion on the east coast of Spain: wear of particles, mineral composition, carbonates and Posidonia oceanica. Sci. Total Environ. 572, 487-497.

Milliman, J.D., Syvitski, J.P.M., 1992. Geomorphic/tectonic control of sediment discharge to the ocean: the importance of small mountainous rivers. J. Geol. 100 (5), 525-544.

Newton, A., Carruthers, T.J.B., Icely, J., 2012. The coastal syndromes and hotspots on the coast. Estuar. Coast. Shelf Sci. 96, 39-47.

Oliveira, S., Moura, D., Horta, J., Nascimento, A., Gomes, A., Veiga-Pires, C., 2017. The morphosedimentary behaviour of a headland-beach system: quantifying sediment transport using fluorescent tracers. Mar. Geol. 388, 62-73.

Pagán, J.I., Aragonés, L., Tenza-Abril, A.J., Pallarés, P., 2016. The influence of anthropic actions on the evolution of an urban beach: case study of Marineta Cassiana beach, Spain. Sci. Total Environ. 559, 242-255.

Pagán, J.I., López, M., López, I., Tenza-Abril, A.J., Aragonés, L., 2018. Study of the evolution of gravel beaches nourished with sand. Sci. Total Environ. 626, 87-95.

Paterson, D.M., Hagerthey, S.E., 2001. Microphytobenthos in constrasting coastal ecosystems: biology and dynamics. In: Reise, K. (Ed.), Ecological Comparisons of Sedimentary Shores. Springer Berlin Heidelberg, Berlin, Heidelberg, pp. 105-125.

Roberts, J., Jepsen, R., Gotthard, D., Lick, W., 1998. Effects of particle size and bulk density on erosion of quartz particles. J. Hydraul. Eng. 124 (12), 1261-1267.

Roeland, H., Piet, R., 1995. Dynamic preservation of the coastline in the Netherlands. J. Coast. Conserv. 1 (1), 17-28.

Román-Sierra, J., Muñoz-Perez, J.J., Navarro-Pons, M., 2014. Beach nourishment effects on sand porosity variability. Coast. Eng. 83, 221-232.

Steinfeldt, R., Rhein, M., Bullister, J.L., Tanhua, T., 2009. Inventory changes in anthropogenic carbon from 1997-2003 in the Atlantic Ocean between $20^{\circ} \mathrm{S}$ and $65^{\circ}$ N. Glob. Biogeochem. Cycles 23 (3)

Trembanis, A.C., Pilkey, O.H., 1998. Summary of beach nourishment along the U.S. Gulf of Mexico shoreline. J. Coast. Res. 14 (2), 407-417.

Une 103 100: 1995, 1995. Sample preparation for soil tests. In: Standardization Technical Committee AEN/CTN 103 - Geotechnics, Available online http://www. aenor.es/aenor/normas/normas/fichanorma.asp?tipo $=\mathrm{N} \&$ codigo $=\mathrm{N} 0007827 \#$. WIHClfnhCUk, (8).

Une 103 101: 1995, 1995. Particle size analysis of a soil by screening. In: Standardization Technical Committee AEN/CTN 103 - Geotechnics, Available online http:// www.aenor.es/aenor/normas/normas/fichanorma.asp?tipo $=\mathrm{N} \&$ codigo $=$ N0007828\#.WIHC vnhCUk, (10).

Une 103 200: 1993, 1993. Determination of carbonate content in soils. In: Standardization Technical Committee AEN/CTN 103 - Geotechnics, Available online http:// www.aenor.es/aenor/normas/normas/fichanorma.asp?tipo=N\& codigo $=$ N0007837\#.WrC-TOjOWUk, (6).

Une 7050-2: 1997, 1997. Test sieves. Metal wire cloth, perforated metal plate and electroformed sheet. Nominal size of openings. In: Standardization Technical Commit- 
tee AEN/CTN 7 - Materials testing, Available online http://www.aenor.es/aenor/ normas/normas/fichanorma.asp?tipo $=\mathrm{N} \& \operatorname{codigo}=\mathrm{N} 0000151$ \#.WIHCyfnhCUk, (8).

Van Ledden, M., Van Kesteren, W.G.M., Winterwerp, J.C., 2004. A conceptual framework for the erosion behaviour of sand-mud mixtures. Cont. Shelf Res. 24 (1), $1-11$.

Van Rijn, L.C., 2007. Unified view of sediment transport by currents and waves. I: initiation of motion, bed roughness, and bed-load transport. J. Hydraul. Eng. 133 (6), 649-667.

Venditti, J.G., Dietrich, W.E., Nelson, P.A., Wydzga, M.A., Fadde, J., Sklar, L., 2010 Effect of sediment pulse grain size on sediment transport rates and bed mobility in gravel bed rivers. J. Geophys. Res. Earth Surf. 115 (F3), (F03039)

Venditti, J.G., Dietrich, W.E., Nelson, P.A., Wydzga, M.A., Fadde, J., Sklar, L., 2010. Mobilization of coarse surface layers in gravel-bedded rivers by finer gravel bed load. Water Resour. Res. 46 (7), (W07506)

Wilcock, P.R., Kenworthy, S.T., Crowe, J.C., 2001. Experimental study of the transport of mixed sand and gravel. Water Resour. Res. 37 (12), 3349-3358.

Williams, A., Rangel-Buitrago, N.G., Pranzini, E., Anfuso, G., 2017. The management of coastal erosion. Ocean Coast. Manag.

A summary of the most representative data obtained after the tests, including an overview of the characteristics of the samples studied, is provided due to the large number of samples, tests and data generated by the study. Detailed information about statistical analysis can be found in Table S1 (Supplementary material).

- Cycles (n): refers to the number of APW cycles needed to reduce the total grain sample to sizes $<0.063 \mathrm{~mm}$, indicating the end of its useful life and thus of the test.

- Particle size distribution: refers to the data obtained from particle size distribution tests.

- D0 and Dn: refer to median sediment size $\mathrm{D}_{50}$ before undergoing the APW test, in the first cycle (0), and in the last cycle (n), once the APW test has been carried out. In both cases, the results include all the particles that comprise the sample.

- D01, Du and D0n: refer to the diameter loss in percentage (\%) between cycle 0 and cycle $1(01)$, in the last cycle $(\mathrm{u})$, and between cycle 0 and cycle $n(0 n)$ of the APW test.

- M0 and Mn: refer to weight in grams before cycle 0 and after cycle $\mathrm{n}$ of the APW test. In neither case, were the particles $0.063 \mathrm{~mm}$ computed.

- M01, Mu and M0n: refer to weight loss in percentage between cycle 0 and cycle $1(01)$, in the last cycle (u), and between cycle 0 and cycle $\mathrm{n}(0 \mathrm{n})$ of the APW test.

- S0 and Sn: refer to the average of the specific surface area (SSA) in $\mathrm{mm}^{2}$ before cycle 0 and after cycle $\mathrm{n}$ of the APW test. In both cases, the results include all the particles that comprise the sample.
- S0n: refers to the increase of SSA in percentage between cycle 0 and cycle $n(0 n)$.

- $\mathrm{CaCO}_{3}$ : refers to the amount of calcium carbonate dissolved in water accumulated in the $\mathrm{n}$ cycles of the APW test.

- Mineralogy: refers to the mineralogical composition of the sand sample in percentage (Rietveld analysis).

Statistical summary of all the variables under study. It includes such measurements as central tendency, variability and distribution arrangement. Particularly relevant are those features that determine whether the sample agrees with the normal Gauss Bell distribution, as is the case of the standardized Bias and Kurtosis. The values outside the range, i.e., between -2 and +2 , indicate significant deviation from the norm. The analysis was complemented with Box and Whiskers charts for variables showing statistics outside the normal range detected. Values distant from the norm were identified applying the Tukey test either as being three times greater than the interquartile range, or external - 1.5 times greater than the interquartile range. Outliers, samples with extreme values, were identified by the Grubb test. For Grubb, any value of $\mathrm{p}<0.05$ means that this value is a significant aberrance. Students' statistics were also analysed, which measures the number of sample standard deviations from the average. All the information is listed in the supplementary material (Table S1).

Table 3 shows a generalized tendency between D01 and M01 in the linear correlation matrix. Both the median diameter loss of all the particles and the mass loss of the particles $>0.063 \mathrm{~mm}$ increase in a linear correlation coefficient of $r=0.78, R^{2}=0.61$. When samples outside the normal range are detected (Fig. 2; see Table S1 in the supplementary material), they are eliminated $(7,14,23)$, the correlation decreases to $r=0.62, R^{2}=0.39$. However, this loss is not proportional to the initial sand sample size as seen in Table 3. A weak correlation coefficient is seen between D0 and M01 $(r=-0.25)$, and between D0 and D01 $(r=-0.25)$. It follows that beaches exist whose sediment contains a significant proportion of particles $<0.063 \mathrm{~mm}$ whose D0 value is low, and whose D01 value is lower than other samples with larger initial median diameter as is the case of Aguamarina (2) $4.2 \%$, Acapulco (1) 4.9\%, and Playa San Juan (25) 2.7\%, shown in Table 2. 